prof. dr inż. Agnieszka Merkisz-Guranowska,

dr inz. Jarostaw Czerwiński,

dr inz. Maciej Andrzejewski,

dr inz. Pawel Daszkiewicz

Instytut Pojazdów Szynowych „,TABOR”

Politechnika Poznańska

\title{
The environmental analysis of semi-trailers carriage in the intermodal transport
}

\section{Analiza środowiskowa przewozu naczep w transporcie intermodalnym}

\begin{abstract}
In the paper the environmental nuisance of transport of goods loaded in semi-trailers was analysed, using both road and rail transport. In the second case the transport of semi-trailers using intermodal wagons pulled by the diesel locomotive was taken into account. The ecological aspects focused on such harmful compounds as: carbon monoxide, hydrocarbons and nitrogen oxides.
\end{abstract}

W artykule przeprowadzono analizę uciqżliwości środowiskowej przewozu towarów naczepami, $z$ wykorzystaniem zarówno transportu drogowego, jak i kolejowego. W tym drugim przypadku uwzględniono transport naczep przy wykorzystaniu intermodalnych wagonów kolejowych ciagniętych przez lokomotywe spalinowa. Aspekty ekologiczne koncentrowaty się na takich szkodliwych zwiqzkach, jak: tlenek węgla, węglowodory i tlenki azotu.

\section{INTRODUCTION}

The dynamic development of transport recorded in recent decades is an important factor in the economic development of the world on the one hand, and on the other hand, it is a significant source of nuisance and environmental problems. The adverse impact of transport can be felt both in the natural environment and in society, where the dynamic development of this sector has enabled significant civilization development, with the effects varying depending on the level of economic development, the degree of advancement and use of the various transport sectors, geographical location (including climate), and also the sensitivity of the elements of the environment. Considering contemporary transport hazards, it is important to prevent them from occurring, and when that is not possible - limiting their impact on the environment and reducing the scale and extent of negative impacts.

One of the main objectives of the European Transport Policy (EPT) is to increase the share of alternative modes of transport - revitalization of rail transport, promotion of water transport and development of intermodal transport, which will help to reduce the dominance of road transport. In the European Union, railways account for $6.3 \%$ of total passenger transport and $10.9 \%$ of freight [5]. By 2020 it is planned to increase the share of railways in passenger transport to $10 \%$ and in freight to $15 \%$, which should significantly reduce the negative impact of transport on the environment [5].

\section{WPROWADZENIE}

Dynamiczny rozwój transportu notowany w ostatnich dekadach jest istotnym czynnikiem rozwoju gospodarczego świata $\mathrm{z}$ jednej strony, $\mathrm{z}$ drugiej natomiast jest znaczącym źródłem uciążliwości i problemów środowiskowych. Niekorzystny wpływ transportu odczuwalny jest zarówno w środowisku przyrodniczym, jak i w społeczeństwie, któremu dynamiczny rozwój tego sektora umożliwił dokonanie znaczącego rozwoju cywilizacyjnego, przy czym efekty te różnią się w zależności od poziomu rozwoju gospodarczego, stopnia zaawansowania i wykorzystania różnych sektorów transportu, położenia geograficznego (w tym klimatu), a także wrażliwości elementów środowiska. Rozpatrując współczesne zagrożenia ze strony transportu istotne jest zapobieganie ich występowaniu, a gdy nie jest to możliwe - ograniczanie ich wpływu na środowisko oraz redukcja skali i zasięgu negatywnych skutków.

Jednym z głównych celów Europejskiej Polityki Transportowej (EPT) jest zwiększenie udziału alternatywnych form transportu - rewitalizacja transportu kolejowego, promowanie transportu wodnego i rozwój transportu intermodalnego, co ma przyczynić się do zmniejszenia dominacji transportu drogowego. W Unii Europejskiej kolej realizuje 6,3\% całkowitego transportu pasażerskiego oraz $10,9 \%$ transportu towarowego [5]. Do roku 2020 planuje się zwiększenie udziału kolei w przewozach pasażerskich 
The impact of rail transport on the environment and safety is much lower compared to road transport. The impact of rail transport on the environment mainly relates to the emission of noise and vibration, pollution (from diesel locomotives) and land occupation. The emission of pollutants from rail transport in the European Union is estimated at $1-3 \%$ of total emissions from transport [3]. According to the European Environment Agency, rail transport in the EU accounts for $1.5 \%$ of total $\mathrm{NO}_{\mathrm{x}}$ emissions [6].

\section{ANALYSIS OF EMISSIONS PER UNIT OF ENERGY}

For the purposes of article, an environmental analysis was carried out to compare the environmental impact of the carriage of 38 semi-trailers with a capacity of $24 \mathrm{Mg}$ by road transport and by rail transport. The two transport options were compared, the first was a conventional road transport using longhaul trucks. The second option was to transport the same 38 semi-trailers using combined transport method with the use of the road-rail transport system of standard semi-trailers. For calculations it was assumed that the railcars would be pulled by a diesel locomotive. This is a more impactful environmental version of transport compared to the use of electric locomotives. This choice was made to assess the maximum environmental burden of combined transport in the worst case. It was assumed that one train will use 19 wagons to transport semitrailers, where two semi-trailers could be fitted per wagon, which corresponds to the transport of 38 semi-trailers, with the length of the double wagon reaching $31.06 \mathrm{~m}$ and the total length of the train not exceeding $600 \mathrm{~m}$.

Evaluation of the road transport option assumes the use of 38 long-haul trucks to transport 38 semi-trailers. Due to the very wide age range of long-haul trucks in operation, depending on the type of transport company involved, the transport variant were adopted which assumed the age range of trucks in accordance with the structure given by the GUS (Fig. 1), on the basis of which the EURO emission standard for heavy goods vehicles was determined. The overall composition and age structure of the vehicles, taking into account their emission standards, is the following:

- Euro III 6 trucks,

- Euro IV 7 trucks,

- Euro V 10 trucks,

- Euro VI 15 trucks.

Emission values for the analyzed toxic exhaust gases listed in Table 1 were adopted in accordance with current standards [1]. do $10 \%$, a w towarowych do $15 \%$, co ma znacznie zmniejszyć negatywne oddziaływanie transportu na środowisko naturalne [5].

Skala oddziaływania transportu kolejowego na środowisko i bezpieczeństwo jest znacznie mniejsza w porównaniu do transportu drogowego. Oddziaływanie transportu kolejowego na środowisko sprowadza się głównie do emisji hałasu i drgań, zanieczyszczeń (z lokomotyw spalinowych) oraz zajmowania terenu. Emisja zanieczyszczeń $\mathrm{z}$ transportu kolejowego w Unii Europejskiej jest szacowana na 1-3\% emisji całkowitej pochodzącej z transportu [3]. Zgodnie z danymi Europejskiej Agencji Środowiska wynika, że transport kolejowy w UE odpowiada za 1,5\% całkowitej emisji $\mathrm{NO}_{\mathrm{x}}[6]$.

\section{ANALIZA EMISJI W PRZELICZENIU NA JEDNOSTKE ENERGII}

Na potrzeby artykułu dokonano analizy środowiskowej mającej na celu porównanie uciążliwości dla środowiska przewozu 38 naczep o ładowności $24 \mathrm{Mg}$ transportem drogowym i transportem kolejowym. Porównano dwie możliwości transportu towaru. Pierwszą z nich był konwencjonalny transport drogowy naczep z wykorzystaniem ciagników siodłowych. Druga możliwość zakładała transport tych samych 38 naczep za pomocą kombinowanego transportu $\mathrm{z}$ wykorzystaniem systemu transportu kolejowo-drogowego dla przewozów standardowych naczep samochodowych. Do obliczeń założono, że wagony kolejowe będą ciagnięte przez lokomotywę spalinową. Jest to bardziej uciążliwa środowiskowo wersja transportu w porównaniu z wykorzystaniem lokomotyw elektrycznych. Wyboru takiego dokonano w celu oceny maksymalnych obciążeń środowiskowych transportu kombinowanego. Przyjęto założenie, że jeden skład wykorzystuje 19 wagonów przeznaczonych do transportu naczep, na które ładuje się po dwie naczepy, co odpowiada transportowi 38 naczep drogowych, przy długości podwójnego wagonu 31,06 m i całkowitej długości składu nie przekraczającej $600 \mathrm{~m}$.

Ocena obciążeń w transporcie drogowym zakłada wykorzystanie do transportu 38 naczep 38 ciagników siodłowych. Ze względu na bardzo zróżnicowaną strukturę wiekową ciagników siodłowych, zmienną w zależności od rodzaju przedsiębiorstw transportowych, przyjęto wariant transportowy zakładający strukturę wiekową ciagników siodłowych zgodną ze strukturą podawaną przez GUS (rys. 1), na podstawie której określono normę emisji spalin EURO dla pojazdów ciężarowych. Całościowe ujęcie składu i struktury wiekowej pojazdów przy uwzględnieniu spełnionej przez te pojazdy normy emisji spalin jest następujące:

- Euro III 6 ciągników siodłowych,

- Euro IV 7 ciagników siodłowych,

- Euro V 10 ciagników siodłowych,

- Euro VI 15 ciagników siodłowych. 


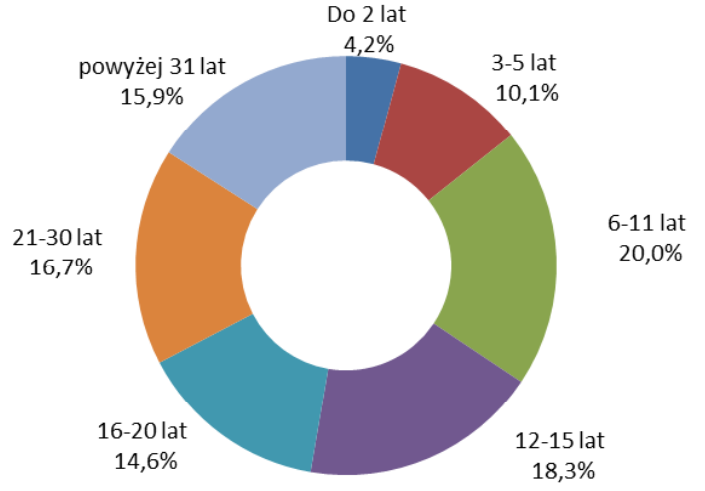

Fig. 1. Age structure of trucks according to GUS data [2] Rys. 1. Struktura wiekowa samochodów ciężarowych według danych GUS [2]

Table 1. Specific emissions of toxic gaseous compounds for the respective emission standards of HDV vehicles [1]

Tabela 1. Wartości emisji poszczególnych gazowych związków toksycznych dla danych norm emisji spalin pojazdów HDV [1]

\begin{tabular}{|l|c|c|c|c|}
\hline & Euro III & Euro IV & Euro V & Euro VI \\
\hline $\begin{array}{l}\mathrm{CO} \\
{[\mathrm{g} / \mathrm{kWh}]}\end{array}$ & 2,1 & 1,5 & 1,5 & 1,5 \\
\hline $\begin{array}{l}\mathrm{HC} \\
{[\mathrm{g} / \mathrm{kWh}]}\end{array}$ & 0,66 & 0,46 & 0,46 & 0,13 \\
\hline $\begin{array}{l}\mathrm{NO}_{\mathrm{x}} \\
{[\mathrm{g} / \mathrm{kWh}]}\end{array}$ & 5,0 & 3,5 & 2,0 & 0,4 \\
\hline
\end{tabular}

To compare the environmental impact of the considered transport options it was necessary to determine the emission values of toxic compounds emitted during the railway transport of semitrailers using diesel locomotives. The experience of authors in this field and market analysis has allowed to indicate the most likely method of train transport of 19 intermodal wagons loaded with 38 semi-trailers with diesel locomotives whose combustion engines meet the values shown in Table 2. For comparative purposes, two diesel locomotives meeting the older exhaust emission standards have been compared: ORE B13, UIC 2003 and one modern locomotive, which propulsion unit met the Stage III standard. The emission values per unit of energy were based on the data contained in the publication [4].

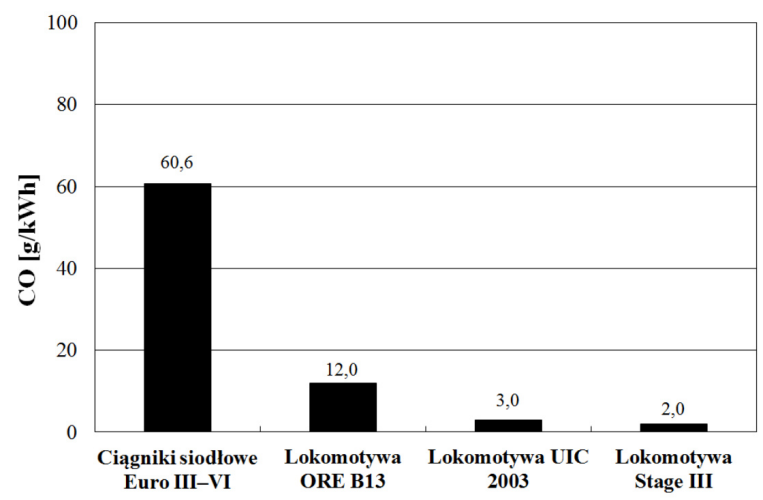

Rys. 2. Porównanie wartości emisji CO przyjętego wariantu transportu drogowego z normami emisji spalin dla lokomotyw spalino

Fig. 2. Comparison of $\mathrm{CO}$ emission values of adopted road transport variant with emission standards for diesel locomotives
Wartości emisji dla analizowanych związków toksycznych spalin zamieszczone $\mathrm{w}$ tabeli 1 przyjęto zgodnie z obowiązującym standardami [1].

Do porównania uciążliwości dla środowiska naturalnego niezbędne było ustalenie wartości emisji związków toksycznych emitowanych $\mathrm{w}$ trakcie transportu kolejowego naczep $\mathrm{z}$ wykorzystaniem lokomotyw spalinowych. Doświadczenie autorów w tej tematyce i analiza rynku pozwoliły na wskazanie najbardziej prawdopodobnego wariantu transportu pociagu składającego się z 19 wagonów intermodalnych, transportujących 38 naczep za pomocą lokomotyw spalinowych, których silniki spalinowe spełniały przedstawione $\mathrm{w}$ tabeli 2 wartości emisji. W celach porównawczych wskazano dwie lokomotywy spalinowe spełniające starsze normy emisji spalin: ORE B13, UIC 2003 oraz jedną nowoczesną lokomotywę, której jednostka napędowa spełniała normę Stage III. Wartości emisji na jednostkę energii przyjęto na podstawie danych zawartych w publikacji [4].

Table 2. Exhaust gas emission values of individual gaseous toxic compound norms for locomotives [4]

Tabela 2. Wartości emisji poszczególnych gazowych związków toksycznych dla danych norm emisji spalin lokomotyw spalinowych [4]

\begin{tabular}{|l|c|c|c|}
\hline \multirow{2}{*}{$\begin{array}{l}\text { Substancja } \\
\text { toksyczna } \\
\text { Toxic sub- } \\
\text { stance }\end{array}$} & \multicolumn{3}{|c|}{$\begin{array}{c}\text { Dopuszczalna emisja zanieczyszczeń } \\
\text { [g/kWh] }\end{array}$} \\
\cline { 2 - 4 } Permissible exhaust emission [g/kWh] & ORE 13 & UIC 003 & Stage III \\
\hline $\mathrm{CO}$ & 12,0 & 3,0 & 2,0 \\
\hline $\mathrm{HC}$ & 4,0 & 0,8 & 0,5 \\
\hline $\mathrm{NO}_{\mathrm{x}}$ & 24,0 & 9,5 & 6,0 \\
\hline
\end{tabular}

Na rysunkach 2-4 przedstawiono sumaryczne wartości emisji związków toksycznych dla rozpatrywanej możliwości transportu 38 naczep przy wykorzystaniu ciągników siodłowych. Rozszerzając analizę o możliwość transportu tego samego towaru za pomocą transportu intermodalnego z wykorzystaniem 19 wagonów kolejowych przystosowanych do załadunku dwóch naczep każdy wykazano, iż transport kolejowy z wykorzystaniem nawet najstarszej lokomotywy spalinowej, której silnik spalinowy spełniał normę emisji spalin ORE B13 jest bardziej przyjazny dla środowiska naturalnego i wartości emisji związków toksycznych są mniejsze niż w przypadku tego samego transportu z wykorzystaniem 38 ciagników siodłowych.

\section{PODSUMOWANIE}

Przedstawiona na rysunkach 5-7 różnica w emisji dla $\mathrm{CO}, \mathrm{HC}$ i $\mathrm{NO}_{\mathrm{x}}$ wykazała jednoznacznie, iż transport naczep z wykorzystaniem specjalnych wagonów drogą kolejową w mniejszym stopniu negatywnie oddziałuje na środowisko naturalne. Wykazane różnice wahają się od ok. 300\% dla najstarszych eksploatowanych na torach kolejowych lokomotyw spalinowych, 
Rys. 2. Porównanie wartości emisji CO przyjętego wariantu transportu drogowego z normami emisji spalin dla lokomotyw spalinowych

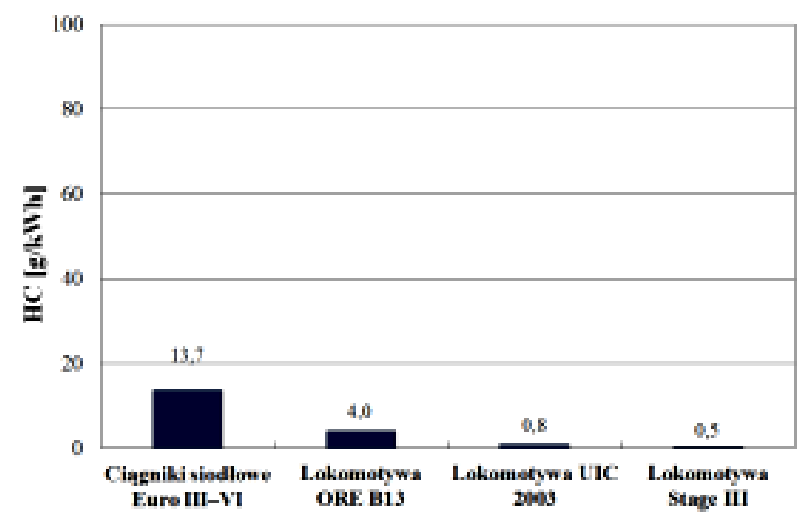

Fig. 3. Comparison of $\mathrm{HC}$ emission values of adopted road transport variant with emission standards for diesel locomotives

Rys. 3. Porównanie wartości emisji HC przyjętego wariantu transportu drogowego z normami emisji spalin dla lokomotyw spalinowych

In Figures 2-4 the comparison of total emission values of toxic compounds for the considered transport option of 38 semi-trailers by using trucks was shown. By extending the analysis to include the possibility of transporting the same goods by means of intermodal transport with the use of 19 rail cars adapted to loading two semi-trailers each, it has been shown that rail transport using even the oldest diesel locomotive, whose combustion engine meets the emission standard ORE B13, is more environmentally friendly and emissions of toxic compounds are lower than for the same transport using 38 modern long-haul trucks.

\section{SUMMARY}

As shown in Figures 5-7, the difference in emission for $\mathrm{CO}, \mathrm{HC}$ and $\mathrm{NO}_{\mathrm{x}}$ clearly showed that, the use of rail transport has a less significant impact on the environment. The discrepancies vary from about $300 \%$ for the oldest diesel locomotive engines of the ORE B13 norm, up to $3000 \%$ for state-of-the-art diesel locomotives equipped with a Stage III emission compliant diesel engine.

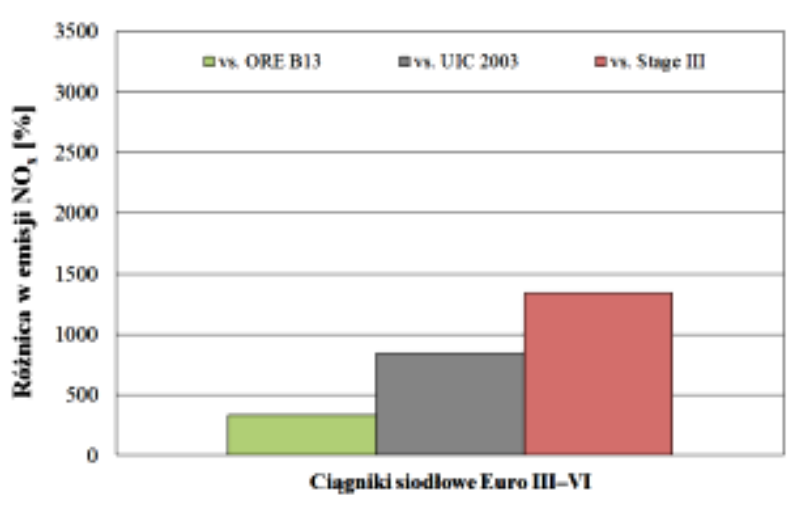

Fig. 7. Difference in $\mathrm{NO}_{\mathrm{x}}$ emissions for adopted road transport variant versus combined transport

Rys. 7. Różnica w emisji $\mathrm{NO}_{\mathrm{x}}$ dla przyjętego wariantu transportu drogowego w stosunku do transportu kombinowanego

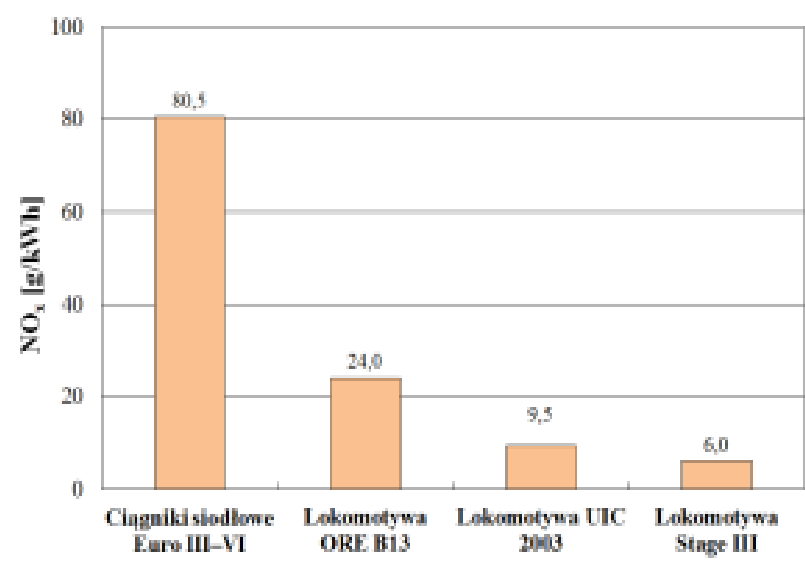

Fig. 4. Comparison of $\mathrm{NO}_{\mathrm{x}}$ emission values of adopted road transport variant with emission standards for diesel locomotives Rys. 4. Porównanie wartości emisji $\mathrm{NO}_{\mathrm{x}}$ przyjętego wariantu transportu drogowego z normami emisji spalin dla lokomotyw spalinowych

których silniki spełniają normę emisji spalin ORE B13, do aż 3000\% dla nowoczesnych lokomotyw spalinowych wyposażonych $\mathrm{w}$ jednostkę napędową spełniającą normę toksyczności spalin Stage III.

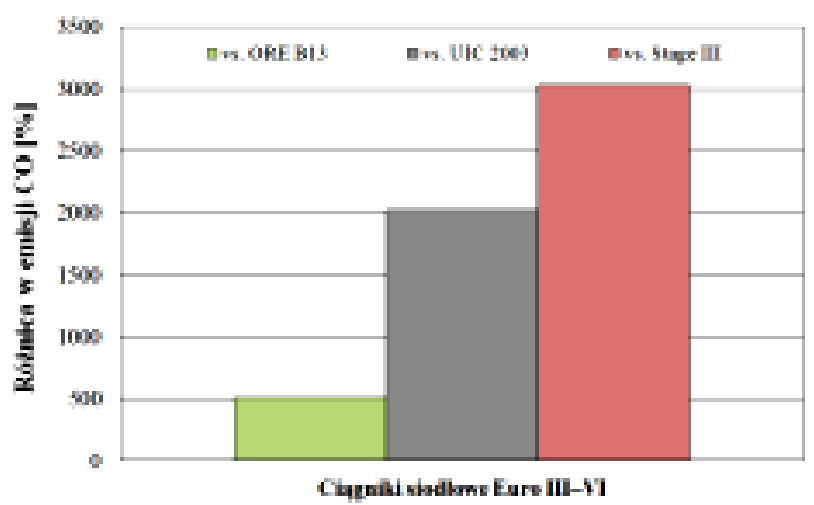

Fig. 5. Difference in CO emissions for adopted road transport variant versus combined transport

Rys. 5. Różnica w emisji CO dla przyjętego wariantu transportu drogowego w stosunku do transportu kombinowanego

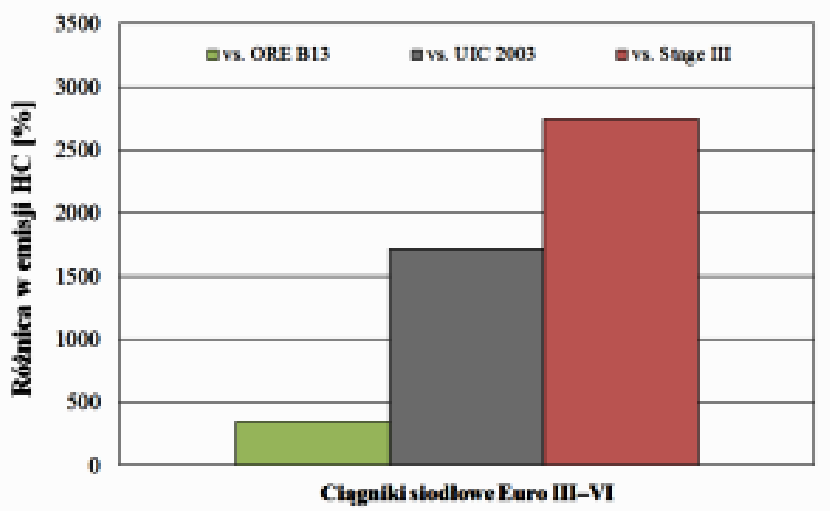

Fig. 6. Difference in $\mathrm{HC}$ emissions for adopted road transport variant versus combined transport

Rys. 6. Różnica w emisji HC dla przyjętego wariantu transportu drogowego w stosunku do transportu kombinowanego 
Development of multimodal transport improves the prospects for global markets. In the case of Poland it is possible to strengthen the country as a liaison between Western Europe and Eastern Europe and Russia. For customers on long haul routes, multimodal transport gives economic advantages and enables savings. The most important economic benefits of combined transport are generated at a macroeconomic level in a broad socio-economic context. As for the benefits in terms of ecological aspects, they occur when modern diesel locomotives are used for transport. The use of old rolling stock causes high levels of pollutant emissions in the exhaust gases, however it is "competitive" with regard to the transportation of numerous long-haul trucks.

\section{BIBLIOGRAPHY}

Dzięki rozwojowi transportu multimodalnego polepsza się perspektywa rozwoju rynków globalnych. W przypadku Polski daje to możliwość umocnienia kraju na pozycji łącznika między Europą Zachodnią a Europa Wschodnią oraz Rosją. Z punktu widzenia klientów usług transportowych na dalekich trasach, transport kombinowany może przynosić oszczędności. Najważniejsze korzyści ekonomiczne transport kombinowany generuje na poziomie makroekonomicznym, w szerokim ujęciu społeczno-gospodarczym. Jeżeli chodzi o korzyści w aspektach ekologicznych to występują one przy zastosowaniu w przewozach nowoczesnych lokomotyw spalinowych. Korzystając jak do tej pory ze starego taboru kolejowego, emisja jednostkowa zanieczyszczeń $w$ spalinach utrzymuje się na wysokim poziomie, choć i tak jest „konkurencyjna” wobec przewozów licznymi ciagnikami siodłowymi.

\section{BIBLIOGRAFIA}

1. Delphi Automotive Ltd, Worldwide emissions standards 2016/2017 Heavy Duty and Off-Highway vehicles, Gillingham, United Kingdom, 2016.

2. Główny Urząd Statystyczny, Transport. Wyniki działalności w 2015, Warszawa 2016.

3. Ministerstwo Infrastruktury i Rozwoju, Dokument implementacyjny do strategii rozwoju transportu do 2020 r. (z perspektywa do 2030 r.). Warszawa, październik 2014.

4. Pielecha I., Pielecha J.: Tendencje $w$ przepisach dotyczacych emisji zwiqzków toksycznych przez silniki pojazdów szynowych. Pojazdy Szynowe, nr 1/2005.

5. Rail Transport and Environment FACT\&FIGURES, The Voice of European Railways, UIC International Union Of Railways, Paris, 2015.

6. https://www.eea.europa.eu/pl (dostęp w dniu 20.09.2017). 